\title{
Pengembangan, Implementasi dan Pembuatan Perangkat Asesmen Berbasis Kelas untuk Pembelajaran Mata Kuliah Sistem Pemindah Tenaga
}

\author{
Wakhinuddin S. \\ Jurusan Teknik Otomotif FT UNP Padang
}

\begin{abstract}
ABSTRAK: Penelitian ini bertujuan mengembangkan, mengimplementasikan dan membuat perangkat asesmen berbasis kelas yang valid, praktis, dan efektif untuk menilai pemahaman konsep, kemampuan pemecahan masalah, penalaran, komunikasi, serta koneksi mahasiswa dalam pembelajaran Sistem Pemindah Tenaga (SPT) di Jurusan Teknik Otomotif FT UNP Padang. Perangkat asesmen dirancang guna menunjang pelaksanaan asesmen di jurusan, sesuai tuntutan kurikulum. Berdasarkan hasil ini dirancang prototipe perangkat asesmen berbasis kelas. Metode penelitian yang digunakan adalah gabungan penelitian pengembangan dan eksperimen. Metode eksperimen digunakan rancangan treatment by design. Dalam eksperimen ini dipilih sampel kelas dan mahasiswa secara random. Di kelas eksperimen digunakan perangkat asesmen berbasis kelas, sedangkan di kelas kontrol dilakukan tes tertulis. Data penelitian dikumpulkan melalui observasi kelas, wawancara dengan dosen dan mahasiswa dan tes. Hasil penelitan ditemukan, bahwa kelompok hasil belajar mahasiswa dinilai dengan perangkat asesmen berbasis kelas lebih tinggi daripada kelompok mahasiswa dinilai dengan paper and pencil test. Perangkat asesmen berbasis kelas efektif meningkatkan pemahaman konsep, kemampuan komunikasi, penalaran dan pemecahan masalah mahasiswa.
\end{abstract}

Kata kunci: asesmen berbasis kelas, perangkat penilaian, validitas, praktikalitas, efektivitas, pemahaman konsep, kemampuan pemecahan masalah, penalaran komunikasi.

\begin{abstract}
The research aims to develop, implement, and make a classroom-based assessment tools that validity, practice, and effectiveness to assess understanding of concepts, problem-solving skills, reasoning, communication, and connection of students, in learning Power train in the Department of Automotive Engineering FT UNP Padang. Assessment device designed to support the implementation of assessment in the majors, according to the demands of the curriculum. Based on these results a prototype device designed classroom-based assessment. The research method used is a combination of research and experimental development. This is research Experimental design of treatment methods used by design. In these experiments the samples selected at random classes and students. In the experimental class used classroom-based assessment tools, while the control class performed a written test. Research data were collected through classroom observation, interviews with faculty and students, as well as tests. The results of the research found that the student assessment based on class higher grade than the student group with a paper and pencil evaluate. This method is effective in increasing the understanding of concepts, communication skills, reasoning and problem solving students.
\end{abstract}

Keywords: classroom-based assessment, assessment tool, validity, practice, effectiveness, concept understanding, solving problem ability, logical thinking, communication.

\section{Pendahuluan}

Jurusan Teknik Otomotif FT UNP merupakan jalur pendidikan profesional yang membekali lulusannya dengan keterampilan dan didukung dengan pengetahuan dasar yang cukup, serta sikap dan disiplin yang tangguh. Tujuan program studi Teknik Otomotif yaitu: 1) Menghasilkan tenaga ahli madya (supervisor) di bidang otomotif untuk sektor kerja pembuatan dan perakitan (manufacturing/assembling), jasa penjualan/perawatan (sales/maintenance) dan alatalat berat (heavy equipment), sebagai lulusan yang profesional, adaptif terhadap perkembangan Iptek khususnya dalam bidang Teknik Otomotif; 2) Meningkatkan daya saing tamatan baik lokal maupun 
nasional dan; 3) Menjadi Program studi Teknik otomotif yang terbaik di bidang teknik otomotif (Buku Pedoman Akademik UNP tahun 2007/2008).

Pada prinsipnya UNP menerapkan kurikulum berbasis kompetensi. Salah satu yang mendasar dengan diterapkannya kurikulum berbasis kompetensi adalah perubahan asesmen pembelajaran. Kegiatan asesmen pembelajaran selama ini cenderung hanya pada aspek kognitif yang diukur melalui paper and pencil test. Sementara, kurikulum berbasis berbasis kompetensi (KBK) mengisyaratkan untuk diterapkannya asesmen berbasis kelas, di mana asesmen terhadap mahasiswa dilakukan secara komprehensif dan berkelanjutan.

Khusus untuk mata kuliah Sistem Pemindah Tenaga (SPT) pada jurusan Teknik Otomotif, perubahan bentuk asesmen juga dituntut oleh adanya perubahan paradigma. Perubahan dari evaluasi dengan menggunakan kertas dan pensil ke evaluasi autentik, dengan prinsip: evaluasi yang relevan dan bermakna bagi mahasiswa, evaluasi yang menggunakan masalah dengan konteks yang jelas, evaluasi yang menekankan pada keterampilan yang kompleks, evaluasi yang tidak menuntut satu jawaban benar, evaluasi yang berdasarkan pada standar yang telah ditetapkan lebih dulu, evaluasi yang mempertimbangkan kecepatan dan pertumbuhan mahasiswa secara individual.

Dari evaluasi sesaat ke evaluasi terus me-nerus, sebagai dasar evaluasi oleh pengajar, dan orang tua. Perubahan penekanan dari evaluasi individual ke evaluasi kelompok, men-cakup: keterampilan proses dalam kelompok, dan hasil dari kerja sama (kolaboratif). Perubahan dari evaluasi aspek tunggal ke evaluasi multidimen-sional, meliputi: pengakuan bahwa mahasiswa memiliki berbagai kemampuan dan bakat, pengakuan bahwa kemampuan mahasiswa dapat dikembangkan, kesempatan bagi mahasiswa untuk mengembangkan dan menunjukkan kemampuannya yang beraneka ragam.

Dari pengalaman selama ini dapat, ada empat fungsi belajar otomotif, yaitu: 1) otomotif sebagai pembelajaran sistem; 2) otomotif sebagai pembelajaran pemecahan masalah; 3 ) otomotif meningkatkan belajar induktif; 4) otomotif sebagai peningkatan kesadaran menghargai benda. Fungsi ini tergambar dalam tujuan program studi yang tercantum dalam tujuan program. Kompetensi utama program studi otomotif FT UNP adalah mampu memahami dan menerapkan ilmu-ilmu dasar seperti otomotif, fisika, kimia ke dalam perencanaan, dan penghitungan di bidang otomotif; mampu berkomunikasi lisan dan tertulis menggunakan Bahasa Inggris; mampu merencanakan pekerjaan, membagi tugas, mensupervisi dan mengontrol pekerjaan tenaga teknisi untuk sektor kerja manufaktur/ assembling, jasa perbengkelan/penjualan, serta alatalat berat.

Untuk mengukur dan menilai ketercapaian kompetensi tersebut, paper and pencil test dirasa tidak lagi memadai, sehingga diperlukan berbagai alternatif bentuk asesmen. Melalui penelitian ini dikembangkan perangkat asesmen berbasiss kelas yang nantinya diharapkan dapat menilai kemampuan otomotif mahasiswa secara otentik dan komprehensif.

Penelitian ini dilandasi oleh keinginan untuk memberikan kontribusi dalam memecahkan permasalahan asesmen yang dihadapi dosendosen teknik otomotif di FT UNP. Keinginan ini direalisasikan dengan merancang perangkat asesmen berbasis kelas untuk pembelajaran SPT di jurusan Teknik otomotif UNP. Secara lebih spesifik penelitian ini bertujuan untuk mengembangkan dan mengimplementasikan perangkat asesmen berbasis kelas yang valid, praktis dan efektif. Istilah valid, praktis dan efektif yang digunakan mengacu pada kriteria yang dikemukakan oleh Guskey (2000).

Dalam penelitian ini cakupan ketiga kriteria tersebut dibatasi sebagai berikut: 1) Perangkat asesmen berbasis kelas dikatakan valid atau mencerminkan state of the art knowledge jika perangkat tersebut oleh pakar pendidikan teknik otomotif dan pakar evaluasi dinyatakan layak digunakan untuk mengukur pemahaman konsep, kemampuan pemecahan masalah, penalaran, komunikasi, dan koneksi mahasiswa. 2) Praktis mengacu pada kondisi di mana dosen dan mahasiswa dapat menggunakan perangkat asesmen berbasis kelas sesuai dengan kriteria yang diharapkan. 3) Perangkat asesmen berbasis kelas dikatakan efektif jika dapat meningkatkan pemahaman konsep, kemampuan pemecahan masalah, penalaran, komunikasi, dan koneksi mahasiswa. Di samping itu, hasil asesmen dengan menggunakan perangkat ini dapat digunakan oleh dosen-dosen teknik otomotif 
untuk mendeskripsi-kan profil hasil belajar mahasiswa secara otentik dan komprehensif.

Penelitian ini diharapkan dapat memberi manfaat, terutama dalam memperkaya referensi bagi dosen, di tengah ketiadaan sumber dan "kebingungan" mereka untuk melaksanakan asesmen sesuai dengan tuntutan Kurikulum (KBK). Di samping itu, pengalaman yang diperoleh dosen-dosen melalui kolaborasi dengan tim peneliti selama pelaksanaan penelitian, diharapkan menjadi pengetahuan dan keterampilan yang dapat mereka terapkan dalam merancang asesmen untuk topik-topik otomotif yang lain.

Persoalan yang berkembang di jurusan teknik otomotif dewasa ini adalah dosen mengalami kesulitan untuk merancang dan menerapkan asesmen seperti yang diinginkan oleh Kurikulum. Hal ini disebabkan karena kurangnya pengetahuan dosen tentang berbagai teknik asesmen (selain dari paper and pencil test), bagaimana cara merancang, serta bagaimana cara pelaksanaannya. Di lain pihak, tuntutan di jurusan (terutama untuk penilaian akhir semester) menghendaki dosen untuk melaksanakan asesmen secara komprehensif.

Hasil wawancara tim peneliti dengan beberapa dosen di jurusan Teknik Otomotif FT UNP menunjukkan bahwa pada umumnya mereka belum memahami cara menilai kemampuan pemecahan masalah, penalaran, dan komunikasi mahasiswa. Akibatnya, dalam penetapan nilai mahasiswa, dosen cenderung memberikan angka untuk aspek-aspek tersebut atas dasar "perkiraan" yang sifatnya sangat subjektif, tanpa membuat instrumen khusus untuk mengukur aspek-aspek yang dimaksud. Di samping itu, juga ditemukan asesmen dari dosen yang tidak menilai aspek-aspek lain secara benar.

Mengacu pada permasalahan-permasalahan yang terjadi di jurusan teknik otomotif, serta belum tersedianya perangkat asesmen untuk pembelajaran SPT di jurusan teknik otomotif maka melalui penelitian ini dikembangkan, diimplementasikan dan dibuat perangkat asesmen berbasis kelas untuk pembelajaran SPT. Hasil penelitian ini diharapkan dapat membantu dosen SPT, mengatasi kesulitan mereka dalam melaksanakan asesmen berbasis kelas. Permasalahan yang ingin dipecahkan melalui penelitian ini adalah: bagaimana mengembangkan dan mengimplementasikan perangkat asesmen berbasis kelas yang valid, praktikal, dan efektif untuk pembelajaran otomotif di jurusan teknik otomotif?

\section{Kajian Teori \\ Asesmen Berbasis Kelas}

Mencermati tujuan pembelajaran otomotif yang tercantum dalam kurikulum disadari bahwa tes tertulis yang hanya mengukur aspek kognitif tidak lagi memadai untuk menilai apakah mahasiswa sudah memiliki kompetensi yang diharapkan. Di samping itu, ketercapaian tujuan kurikulum tidak lagi dapat diukur dengan hanya menggunakan satu macam teknik asesmen. Ott (1994) mengatakan: process goals cannot be measured accurately by any one assessment technique. Different techniques must be used over time to see how students are performing on these goals. Dengan demikian, ketercapaian tujuan kurikulum perlu dinilai melalui asesmen yang dilakukan secara otentik dan komprehensif.

Asesmen adalah istilah umum yang mencakup semua metode yang digunakan untuk menilai kinerja individu mahasiswa atau kelompok mahasiswa. Asesmen yang dilakukan secara komprehensif sepanjang proses pembelajaran (berkelanjutan) selanjutnya dikenal dengan asesmen berbasis kelas. McMilan (2001) mengatakan bahwa classroom assessment can be defined as the collection, interpretation, and use of information to help teachers make better decisions. Dari pengertian ini terlihat bahwa asesmen berbasis kelas lebih dari sekedar tes (paper and pencil test) atau pengukuran yang selama ini lazim digunakan untuk mengevaluasi kemajuan belajar mahasiswa.

Pengertian asesmen berbasis kelas yang lain dikemukakan oleh Depdiknas (2003) yaitu: Asesmen berbasis kelas merupakan suatu proses pengumpulan, pelaporan, dan penggunaan informasi tentang hasil belajar mahasiswa dengan menerapkan prinsipprinsip penilaian, pelaksa-naan berkelanjutan, buktibukti autentik, akurat, dan konsisten sebagai akuntabilitas publik.

Dari dua definisi terlihat bahwa proses asesmen berbasis kelas meliputi pengumpulan bukti secara komprehensif yang dilakukan dengan berbagai teknik, untuk menunjukkan pencapaian hasil belajar mahasiswa. Asesmen berbasis kelas dapat mendeskripsikan pencapaian kompetensi dan hasil belajar mahasiswa yang dikemukakan dalam bentuk pernyataan yang jelas tentang standar yang harus 
dan telah dicapai, disertai dengan profil kemajuan belajar mahasiswa dan pelaporan.

Asesmen yang dilakukan dalam pembelajaran kap apa yang diketahui mahasiswa, sedangkan asesmen berbasis kelas bertujuan untuk mengungkap apa yang diketahui dan apa yang dapat dilakukan mahasiswa. Melalui asesmen berbasis kelas dosen tidak hanya mendapat gambaran tentang pemahaman mahasiswa terhadap konsep-konsep otomotif yang telah mereka pelajari. Lebih dari itu, dosen dapat mengungkap sikap dan motivasi mahasiswa terhadap pelajaran otomotif serta kemampuan pemecahan masalah, penalaran, komunikasi, dan koneksi mahasiswa. Menurut McMillan (2001:98), ada empat komponen penting yang perlu diperhatikan dalam menerapkan asesmen ber-basis kelas, yaitu tujuan, pengukuran, evaluasi, dan pemanfaatan hasil asesmen berbasis kelas. Keempat komponen tersebut digambarkan secara skematis, seperti terlihat pada Gambar 1. konvensional pada umumnya hanya dapat mengung-

hasilnya merupakan feedback untuk meningkatkan proses pembelajaran; meningkatkan relevansi pembelajaran otomotif dengan keseharian mahasiswa; membantu dosen untuk lebih fokus terhadap hasil penting yang diharapkan dari pendidikan (selama ini dosen cenderung mengajarkan konsepkonsep otomotif yang terisolasi satu sama lain); mendorong mahasiswa untuk menjadi pemecah masalah yang kompeten, memiliki rasa percaya diri terhadap kemampuannya dalam berpikir secara logis, serta mampu mengkomunikasikan idenya secara jelas. Mahasiswa juga akan menyadari bahwa melalui asesmen berbasis kelas mereka mendapatkan pendidikan yang bermakna, yang mempersiapkan mereka untuk masa depan.

\section{Pemahaman Konsep, Komunikasi, Penalaran, Koneksi, dan Pemecahan Masalah}

Fungsi utama pembelajaran otomotif adalah untuk mengembangkan kemampuan pemahaman konsep, penalaran, komunikasi, koneksi, dan pemecahan

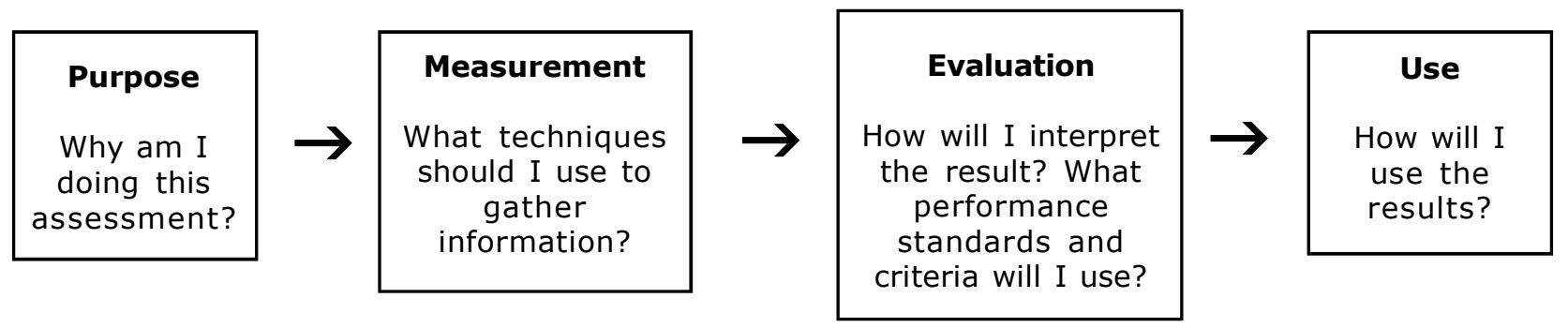

Gambar 1. Komponen-komponen Asesmen Berbasis Kelas

Asesmen berbasis kelas sangat berbeda dengan asesmen konvensional yang pada umumnya dilakukan dosen selama ini. Melalui asesmen berbasis kelas dosen tidak hanya dapat mengembangkan aspek kognitif mahasiswa melainkan juga dapat menumbuhkan kecintaan mahasiswa terhadap otomotif. Menurut Ott (1994:60), ada beberapa keuntungan yang dapat diperoleh melalui pelaksanaan asesmen berbasis kelas, yaitu: Mahasiswa berkompetisi dengan dirinya sendiri, bukan dengan mahasiswa lain; Dapat mengungkapkan pemahaman yang riil tentang apa yang diketahui dan dapat dilakukan mahasiswa; Tidak menakutkan seperti halnya tes tertulis, sehingga dapat mendorong mahasiswa untuk lebih menyukai otomotif serta dapat meningkatkan motivasi mereka; Asesmen berbasis kelas bukanlah suatu "akhir", melainkan bagian integral dari proses pembelajaran, sehingga masalah dalam praktek maupun teori, serta melihat hubungan-hubungan sistem yang terdapat pada suatu mobil (kendaraan), baik antara topik otomotif yang satu dengan yang lain, maupun antara otomotif dengan bidang-bidang ilmu lainnya. Pelaksanaan asesmen berbasis kelas ditujukan untuk mengoptimalkan perkembangan kemampuan mahasiswa untuk tiap aspek tersebut. Berikut ini dibahas pengertian setiap aspek, beserta contoh soal untuk menilainya.

Konsep adalah gambaran secara abstrak suatu fenomena. Konsep merupakan generalisasi dari sekelompok fenomena tertentu, sehingga dapat dipakai untuk menggambarkan berbagai fenomena yang sama. Belajar konsep artinya anak mampu memberi respon terhadap stimulus yang hadir melalui karakteristik abstraknya.

Melalui pemahaman konsep mahasiswa mampu 
mengidentifikasikan benda lain yang berbeda ukuran, warna, maupun materinya, namun masih memiliki kararkteristik dari objek itu sendiri. Dalam kenyataan konsep dapat mempunyai tingkat generalisasi yang berbeda. Semakin dekat suatu konsep kepada realita semakin mudah konsep tersebut diukur dan dievaluasi. Konsep-konsep pada teknik otomotif menggambarkan fenomena alami yang konkrit (karena dapat diketahui dengan panca indera). Dengan demikian konsep pada teknik otomotif dapat dinilai melalui pemahaman konsep tersebut. Pemahaman dalam klasifikasi taksonomi Bloom berada pada kategori ke dua dari tingkat berpikir seseorang.

Pemecahan masalah dalam otomotif adalah proses menemukan penyebab kerusakan dan mengatasi suatu kerusakan yang terjadi dalam suatu sistem otomotif, tugas-tugas, dan situasisituasi dalam keadaan sehariannya. Lebih lanjut dapat dikatakan bahwa masalah-masalah yang dipecahkan meliputi semua topik dalam otomotif baik dalam bidang servis, bongkar-pasang maupun perbaikan. Di samping itu, mahasiswa juga perlu berlatih memecahkan masalah-masalah yang mengkaitkan otomotif dengan sains (natural science, dan social science).

Pemecahan masalah memberikan manfaat yang besar kepada mahasiswa dalam melihat relevansi antara otomotif dengan mata pelajaran lain, serta kehidupan dunia nyata. Mengingat perannya yang begitu potensial banyak pakar pendidikan kejuruan otomotif yang berpendapat bahwa pemecahan masalah adalah bagian yang integral dari semua pembelajaran otomotif, dan merupakan aspek "kunci" untuk dapat mengerjakan semua aspek lain dari otomotif.

Pemecahan masalah merupakan "sarana" sekaligus "target" dari pembelajaran otomotif di kampus. Sebagai sarana, pemecahan masalah memungkinkan mahasiswa untuk mengkonstruksi ide-ide perbaikan. Di samping itu, suatu masalah dapat mengarahkan mahasiswa untuk melakukan investigasi, mengeksplorasi pola-pola kerusakan, dan berpikir secara kritis. Untuk memecahkan masalah, mahasiswa perlu melakukan pengamatan yang cermat, membuat hubungan, bertanya, memperbaiki dan menyimpulkan.

Kemampuan memecahkan masalah seyogyanya merupakan hasil utama dari suatu proses pembelajaran otomotif. Dalam kondisi ini pemecahan masalah dikatakan sebagai target belajar. Mahasiswa harus mampu memecahkan masalah otomotif yang terkait dengan dunia nyata, masalah yang terdapat di dalam buku teks atau yang diberikan oleh dosen. Untuk itu perlu dirancang masalah yang dapat membantu mahasiswa untuk membuat hubungan antara otomotif dengan kehidupan mereka, dan dengan mata pelajaran lainnya. Holmes (1995) mengemukakan kriteria pemecahan masalah yang memungkinkan mahasiswa untuk mencapai target belajar yang dinginkan sebagai berikut:

They need to create an environment that encourages students to explore, take risks, share failures and successes, and question one another. In such supportive environments, students develop the confidence they need to explore problems and the ability to make adjustment in their problem-solving strategies.

Ada beberapa manfaat yang akan diperoleh oleh mahasiswa melalui pemecahan masalah, di antaranya adalah mahasiswa akan belajar bahwa ada banyak cara untuk menyelesaikan suatu kerusakan (berpikir divergen) dan ada lebih dari satu solusi yang mungkin dari suatu kerusakan; mahasiswa terlatih untuk melakukan eksplorasi, berpikir komprehensif, dan bernalar secara sistem dan logis; mengembangkan kemampuan berkomunikasi, dan membentuk nilai-nilai sosial melalui tim kerja kelompok.

Untuk menstimulasi agar mahasiswa mampu menjadi pemecah masalah (problem solver) yang baik, dianjurkan agar pembelajaran otomotif di perguruan tinggi memberi kesempatan kepada semua mahasiswa untuk: membangun pengetahuan dan pengalaman tentang otomotif baru melalui pemecahan masalah; memecahkan masalah baik yang terdapat dalam otomotif, maupun konteks lain; menerapkan berbagai strategi yang cocok dalam memecahkan masalah; memonitor dan melakukan refleksi terhadap proses-proses yang dilakukan dalam memecahkan masalah-masalah otomotif.

Berbagai teknik yang digunakan dalam asesmen berbasis kelas akan memberikan banyak kesempatan kepada mahasiswa untuk membangun dan mengembangkan pengetahuan dan keterampilan seperti dikemukakan di atas. Berikut ini dikemukakan sebuah contoh soal pemecahan masalah untuk topik 
difrensial.

Kerusakan pada gigi samping difrensial pada umumnya disebabkan oleh backclash. Jika backclass distel sesuai dengan spesifikasi gigi samping (side gear) akan awet, jelaskan cara menyetel backclass tersebut.

Penalaran adalah kemampuan utama lain yang ingin dikembangkan melalui pembelajaran otomotif. Struktur keilmuan otomotif dikembangkan dari suatu sistem, mekanisme, serta sifat induktif, membutuhkan kemampuan penalaran empirik yang baik untuk memahaminya. Mengingat pentingnya peran penalaran dalam pembelajaran otomotif, dianjurkan agar penalaran mahasiswa dikembangkan secara terus-menerus, mulai sejak mereka memasuki jurusan teknik otomotif.

Penalaran dapat dilakukan secara induktif (informal) maupun deduktif (formal). Contoh berikut memperlihatkan betapa mahasiswa tingkat 1 mampu melakukan pembuktian dengan kontradiksi (cara pembuktian yang biasanya digunakan setelah belajar Logika Otomotif) menggunakan penalaran informal.

Soal: Buktikan saat suatu mobil berjalan, kenapa terjadi slip pada salah satu roda belakang!

Jawab: Jika koefisien gesek kecil pada salah satu roda belakang maka akan terjadi berputar slip pada roda tersebut dan menyebabkan salah satu roda pada sisi lain tidak berputar/tertahan. Jadi, bila salah satu roda mobil mengalami koefisen gesek kecil dapat membuat roda pada satu sisi lain tidak berputar.

Komunikasi adalah suatu proses di mana kita menjelaskan serta meyakinkan maksud dari sesuatu dalam rangka memperoleh pemahaman bersama. Komunikasi dalam pendidikan otomotif mengandung arti bahwa mahasiswa harus mempelajari bahasa dan simbol-simbol otomotif untuk mengkomunikasikan laporan.

Komunikasi dalam pendidikan otomotif dapat dikembangkan dengan cara memberi mahasiswa berbagai kesempatan untuk mendengarkan, berbicara, menulis, membaca, dan menyajikan ideide matematis. Kemampuan komunikasi mahasiswa juga dapat dikembangkan melalui kerja kelompok, presentasi, dan membuat laporan praktek. Laporan praktek akan mendorong mahasiswa untuk menyampaikan kegiatan yang terjadi selama praktek, sedangkan presentasi memberi kesempatan kepada mahasiswa untuk menyimpulkan atau menjelaskan suatu topik.

Tujuan berkomunikasi tentang otomotif adalah untuk mengekspresikan ide-ide pelayanan dan perbaikan tentang otomotif baik secara lisan maupun tulisan, membaca dan memahami tulisan tentang otomotif, mengkonstruksi pemahaman tentang konsep-konsep otomotif dengan cara menjelaskannya, mengekspresikan pola/hubungan yang ditemukan melalui eksplorasi dan penyelidikan kerusakan.

Adapun objek yang dikomunikasikan dalam pembelajaran otomotif, antara lain dapat berupa kegiatan atau peristiwa yang dialami mahasiswa, atau ide-ide pelayanan dan perbaikan yang dilaksanakannya selama praktek. Berikut ini disajikan beberapa contoh pertanyaan yang ditujukan untuk mengetahui kemampuan komunikasi mahasiswa. Contoh tes: menurut saudara apa bagian yang paling sulit dalam menyelesaikan pekerjaan transmisi empat kecepatan? bagaimana kontribusi tiap anggota kelompok sewaktu praktek bersama kelompok? gambarkanlah apa yang Saudara rasakan tentang pemecahan masalah kerusakan pada kopling mobil; jelaskan bagian mana yang paling penting untuk dipahami tentang kopling mobil; apakah difrensial dan gardan adalah objek yang sama? jelaskan jawabanmu!

Pelaksanaan asesmen melalui pencil and paper test dalam pembelajaran selama ini cenderung mengisolasi otomotif dari bidang-bidang lain, sehingga kemampuan koneksi mahasiswa tidak berkembang. Akibatnya, mahasiswa sangat sulit melihat dan merasakan manfaat mempelajari topiktopik otomotif di kampus. Di samping itu, mahasiswa juga mengalami kesukaran untuk memahami hubungan antara konsep-konsep otomotif yang mereka pelajari dengan konsep-konsep yang mereka pelajari dalam fisika, kimia, mekanika, permesinan atau bidang lainnya.

Melalui teknik asesmen berbasis kelas yang bervariasi, mahasiswa diarahkan untuk melihat koneksi antara konsep-konsep otomotif, maupun koneksi antara otomotif dengan bidang-bidang lain. Berikut ini diberikan sebuah soal untuk menilai kemampuan koneksi mahasiswa pada topik roda gigi. Untuk menemukan perbandingan, jika jumlah gigi pada gigi input 25 dan jumlah gigi pada roda counter gear 50 . Tentukan rasio perbandingan 
Wakhinuddin S., Pengembangan, Implementasi dan Pembuatan Perangkat Asesmen Berbasis Kelas Untuk Pembelajaran Mata Kuliah Sistem ...

gigi!

Contoh di atas menunjukkan koneksi antara otomotif dengan permesinan atau fisika. Pemberian soal-soal koneksi seperti ini dalam pembelajaran otomotif dapat memberi makna kepada mahasiswa bahwa otomotif yang mereka pelajari tidak hanya terkait dengan bidang-bidang lain, melainkan juga dapat digunakan untuk memecahkan masalah-masalah yang mereka jumpai dalam kehidupan sehari-hari.

Menurut McMillan (2001) asesmen berbasis kelas dapat dilakukan dosen melalui berbagai teknik asesmen otentik di antaranya: laporan dalam bentuk portofolio, projek, observasi, presentasi dan diskusi. Asesmen afektif meliputi penghargaan terhadap peralatan dan mesin-mesin, sikap terhadap kebersihan dan keselamatan kerja, disiplin kerja, insiatif, dan tanggung jawab. Psikomotor mencakup kecepatan kerja, kecekatan kerja, ketepatan ukuran dengan spesifkasi (stelan), kesuaian prosedur, dan kerjasama. Perangkat asesmen yang akan dikembangkan dan diimplementasikan dalam penelitian ini menggunakan teknik-teknik seperti dikemukakan di atas. Setiap perangkat akan digunakan untuk menilai pemahaman konsep, kemampuan pemecahan masalah, penalaran, komunikasi, dan koneksi mahasiswa (disesuaikan dengan karakteristik materi ajar).

\section{Metode Penelitian}

Penelitian ini dilaksanakan dengan menggunakan gabungan pendekatan penelitian pengembangan (development research) dan metode eksperimen. Pendekatan penelitian pengembangan digunakan untuk merancang dan mengembangkan perangkat asesmen berbasis kelas yang valid dan praktikal untuk pembelajaran otomotif di jurusan Teknik Otomotif. Metode eksperimen digunakan untuk menyelidiki efektifitas perangkat terhadap pemahaman konsep, kemampuan pemecahan masalah, penalaran, komunikasi, dan koneksi mahasiswa.

Van den Akker (1999), Plomp (2002) mengkarakterisasikan penelitian pengembangan berdasarkan dua tujuannya yaitu: development of prototypical products (curriculum documents and materials), including empirical evidence of their quality; generating methodological directions for the design and evaluation of such products

Menurut Richey, Rita C \& Klein, James D. (2007), penelitian pengembangan adalah upaya untuk mengembangkan dan menghasilkan suatu produk berupa materi, media, alat, atau strategi pembelajaran, digunakan untuk mengatasi masalah pembelajaran di kelas/laboratorium, dan bukan untuk menguji teori. Penelitian pengembangan memiliki tiga tujuan utama, yaitu: 1) menghasilkan rancangan produk yang akan dikembangkan dan digunakan untuk meningkatkan kualitas pembelajaran; 2) menguji keefektifan produk yang telah dibuat sebagai fungsi validasi utama melalui uji coba; 3) menguji keefektifan, efisiensi, dan kemenarikan produk.

Dalam penelitian ini dikembangkan perangkat asesmen berbasis kelas yang valid dan praktikal untuk pembelajaran SPT otomotif di jurusan Teknik Otomotif FT UNP, kemudian akan diuji efektivitasnya. Kegiatan penelitian dilakukan dalam 2 bulan, Rancangan penelitian selengkapnya dapat dilihat pada Gambar 2.

Pada awal penelitian difokuskan untuk merancang prototipe perangkat asesmen berbasis kelas yang valid dan praktikal untuk pembelajaran otomotif. Kegiatan penelitian diawali dengan analisis kebutuhan yang meliputi: menganalisis Kurikulum Otomotif, melakukan wawancara dengan dosen dan mahasiswa, serta mereviu literatur tentang asesmen dan perancangannya. Berdasarkan hasil analisis akan dirancang prototipe perangkat asesmen berbasis kelas, yang berisi: 1 ) tujuan, 2) kisi-kisi (mengacu pada topik dalam silabus SPT), 3) materi asesmen untuk dua topik otomotif; materi asesmen ditujukan untuk menilai pemahaman konsep, kemampuan pemecahan masalah, penalaran, komunikasi, dan koneksi mahasiswa. Teknik asesmen yang digunakan disesuaikan dengan karakteristik topik-topik otomotif yang diajarkan dosen (terdiri dari: laporan praktek dalam bentuk portofolio, proyek, observasi, bertanya, dan presentasi), 4) rubrik penskoran setiap materi asesmen, 5) panduan penggunaan perangkat asesmen berbasis kelas.

Prototipe divalidasi beberapa pakar pendidikan otomotif dan pakar evaluasi. Kegiatan validasi dilakukan dalam bentuk tertulis dan diskusi sampai tercapai suatu kondisi di mana para validator berpendapat bahwa perangkat asesmen yang 


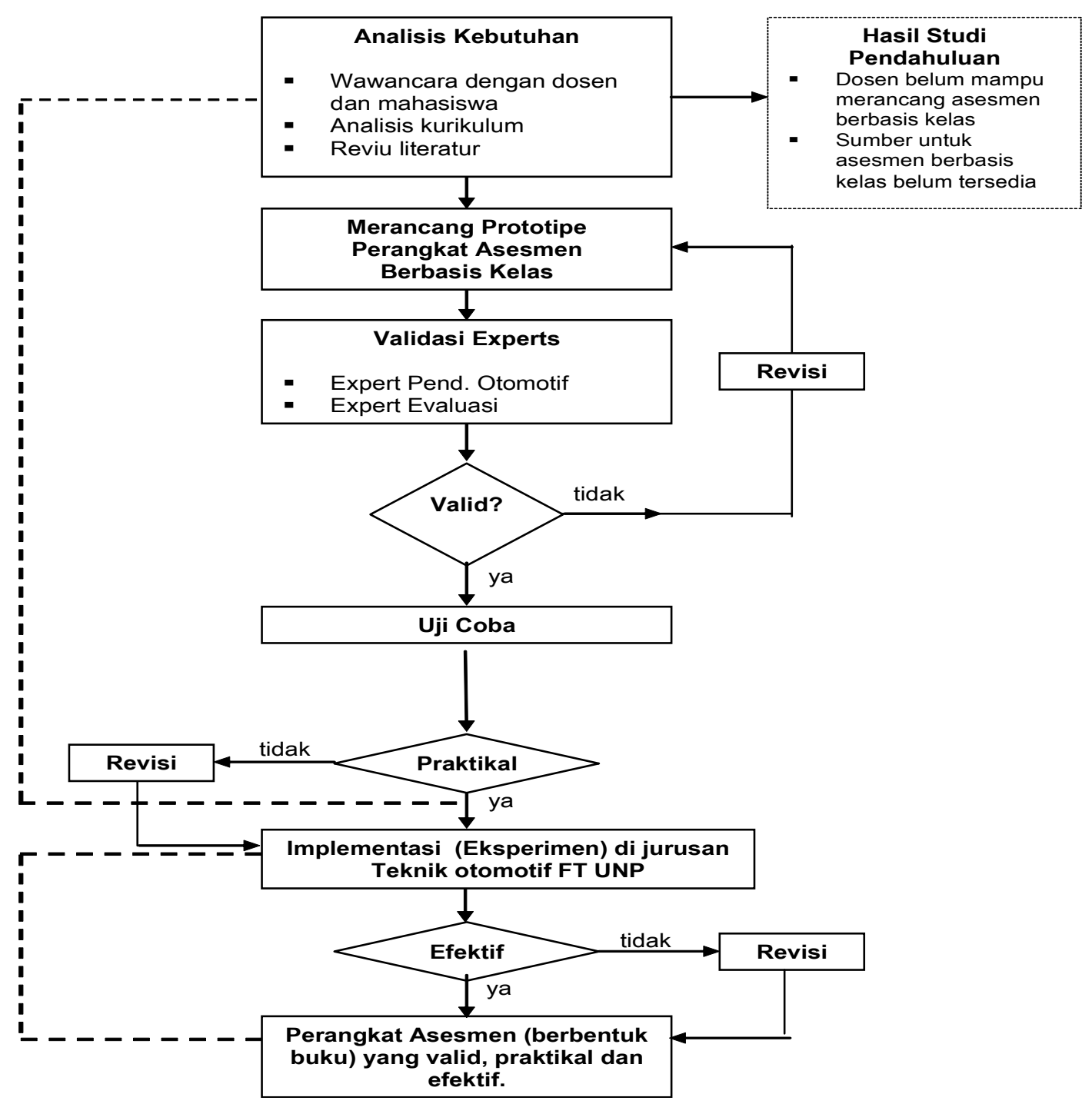

Gambar 2. Rancangan Penelitian

dikembangkan sudah valid dan layak untuk digunakan di kampus.

Aspek validitas difokuskan untuk menjawab beberapa pertanyaan seperti tercantum pada Tabel 1.

Setelah proses validasi dengan para pakar, dilakukan revisi terhadap prototipe perangkat asesmen berbasis kelas. Untuk melihat praktikalitas (keterpakaian), prototipe perangkat hasil revisi selanjutnya akan diujicobakan di kelas noneksperimen di jurusan Teknik Otomotif, pada bulan Oktober 2010.

Uji coba perangkat diharapkan dapat memberikan jawaban terhadap beberapa pertanyaan tentang praktikalitas, seperti tercantum pada Tabel 2. Data penelitian sewaktu uji coba dikumpulkan melalui observasi kelas, wawancara dengan dosen dan mahasiswa, serta analisis laboran praktek (portofolio) mahasiswa. Data yang terkumpul dianalisis secara deskriptif. Hasil analisis akan dijadikan dasar untuk merevisi prototipe.

Perangkat asesmen yang telah direvisi diimplementasikan pada bulan Nopember 2010. Selanjutnya fokus untuk meneliti efektivitas perangkat asesmen berbasis kelas terhadap pemahaman konsep, kemampuan pemecahan masalah, penalaran, komunikasi, serta koneksi mahasiswa. Di samping itu, digali kesan dan pendapat mahasiswa tentang penggunaan perangkat asesmen berbasis kelas. Model pembelajaran yang digunakan untuk mengimplementasikan perangkat pem-belajaran berbasis kelas disesuaikan dengan teknik asesmen yang dirancang.

Metode penelitian yang digunakan metode eksperimen dengan rancangan treatment by design, Tabel 3. Sampel kelas dipilih secara random, dengan 
Wakhinuddin S., Pengembangan, Implementasi dan Pembuatan Perangkat Asesmen Berbasis Kelas Untuk Pembelajaran Mata Kuliah Sistem ...

Tabel 1. Validitas Prototipe Perangkat Asesmen Berbasis Kelas

\begin{tabular}{|c|c|c|}
\hline Objek yang divalidasi & $\begin{array}{c}\text { Metode pengumpulan } \\
\text { data }\end{array}$ & Instrumen \\
\hline $\begin{array}{l}\text { Validitas perangkat asesmen berbasis kelas } \\
\text { 1. Apakah isi perangkat asesmen yang } \\
\text { dirancang sudah memadai untuk menilai } \\
\text { topik-topik otomotif yang dipelajari? } \\
\text { 2. Apakah isi perangkat asesmen sudah dapat } \\
\text { dan tepat digunakan untuk menilai } \\
\text { ketercapaian tujuan kurikulum? } \\
\text { 3. Apakah perangkat asesmen yang dirancang } \\
\text { dapat dan tepat digunakan untuk menilai } \\
\text { pemahaman konsep otomotif mahasiswa? } \\
\text { 4. Apakah perangkat asesmen yang dirancang } \\
\text { dapat dan tepat digunakan untuk menilai } \\
\text { kemampuan pemecahan masalah } \\
\text { mahasiswa? } \\
\text { 5. Apakah perangkat asesmen yang dirancang } \\
\text { dapat dan tepat digunakan untuk menilai } \\
\text { kemampuan penalaran mahasiswa? } \\
\text { 6. Apakah perangkat asesmen yang dirancang } \\
\text { dapat dan tepat digunakan untuk menilai } \\
\text { kemampuan komunikasi mahasiswa? } \\
\text { 7. Apakah perangkat asesmen yang dirancang } \\
\text { dapat dan tepat digunakan untuk menilai } \\
\text { kemampuan koneksi mahasiswa? } \\
\text { 8pakah perangkat asesmen berbasis kelas } \\
\text { yang disusun sudah valid dari segi } \\
\text { konstruksi? }\end{array}$ & $\begin{array}{l}\text { Diskusi dengan } \\
\text { beberapa pakar } \\
\text { pendidikan otomotif } \\
\text { dan pakar evaluasi }\end{array}$ & $\begin{array}{l}\text { Lembar } \\
\text { validasi }\end{array}$ \\
\hline
\end{tabular}

Tabel 2. Praktikalitas Prototipe Perangkat Asesmen Berbasis Kelas

\begin{tabular}{|l|l|l|}
\hline \multicolumn{1}{|c|}{ Objek yang dievaluasi } & \multicolumn{1}{c|}{$\begin{array}{c}\text { Metode pengumpulan } \\
\text { data }\end{array}$} & \multicolumn{1}{c|}{ Instrumen } \\
\hline $\begin{array}{l}\text { Praktikalitas perangkat asesmen berbasis kelas } \\
\text { 1. Apakah perangkat asesmen berbasis kelas } \\
\text { mudah untuk digunakan oleh dosen dan } \\
\text { mahasiswa? }\end{array}$ & $\begin{array}{l}\text { Observasi kelas, } \\
\text { interviu dengan dosen } \\
\text { dan mahasiswa, } \\
\text { analisis hasil kerja } \\
\text { mahasiswa }\end{array}$ & $\begin{array}{l}\text { observasi, } \\
\text { pedoman } \\
\text { 2. Apakah dosen dapat menggunakan } \\
\text { perangkat asesmen berbasis kelas sesuai } \\
\text { dengan pedoman yang diberikan? }\end{array}$ \\
$\begin{array}{l}\text { Apakah waktu yang dirancang untuk } \\
\text { melaksanakan asesmen berbasis kelas } \\
\text { memadai? }\end{array}$ & & \\
\hline
\end{tabular}

jumlah 35 mahasiswa. Di kelas eksperimen digunakan perangkat asesmen berbasis kelas, sedangkan asesmen di kelas kontrol dilakukan secara konvensional (menggunakan paper and pencil test). Selanjutnya pemahaman dan kemampuan mahasiswa kelas eksperimen dan kelas kontrol dibandingkan satu sama lain.

Untuk melihat efektivitas perangkat asesmen berbasis kelas diajukan lima hipotesis penelitian sebagai berikut: 1) pemahaman konsep mahasiswa yang dinilai dengan perangkat asesmen berbasis kelas lebih tinggi daripada pemahaman konsep mahasiswa yang dinilai dengan paper and pencil test; 2) kemampuan pemecahan masalah mahasiswa yang dinilai dengan perangkat asesmen berbasis kelas lebih tinggi daripada kemampuan pemecahan masalah mahasiswa yang dinilai dengan paper and pencil test; 3) kemampuan penalaran mahasiswa yang dinilai dengan perangkat asesmen berbasis kelas lebih tinggi daripada kemampuan penalaran mahasiswa yang dinilai dengan paper and pencil test; 4) Kemampuan komunikasi mahasiswa yang dinilai dengan perangkat 
Tabel 3. Rancangan Penelitian Selanjutnya

\begin{tabular}{|l|l|l|}
\hline \multicolumn{1}{|c|}{$\begin{array}{c}\text { Pemahaman/ } \\
\text { Kemampuan }\end{array}$} & $\begin{array}{c}\text { Kelompok Mahasiswa } \\
\text { dengan Asesmen } \\
\text { Berbasis Kelas }\end{array}$ & $\begin{array}{c}\text { Kelompok Mahasiswa dengan } \\
\text { Paper and Pencil Test }\end{array}$ \\
\hline Konsep & & \\
\hline Pemecahan Masalah & & \\
\hline Penalaran & & \\
\hline Komunikasi & & \\
\hline Koneksi & & \\
\hline
\end{tabular}

asesmen berbasis kelas lebih tinggi daripada kemampuan komunikasi mahasiswa yang dinilai dengan paper and pencil test; 5) kemampuan koneksi mahasiswa yang dinilai dengan perangkat asesmen berbasis kelas lebih tinggi daripada kemampuan koneksi mahasiswa yang dinilai dengan paper and pencil test.

Data penelitian dikumpulkan melalui analisis laporan praktek (portofolio) mahasiswa, observasi kelas, wawancara dengan dosen dan mahasiswa serta tes. Tes yang akan diberikan meliputi tes pemahaman konsep, kemampuan pemecahan masalah, penalaran, komunikasi, dan koneksi. Data yang terkumpul dianalisis menggunakan statistika deskriptif dan inferensial ( $u j i-t)$.

\section{Hasil Penelitian dan Bahasan}

Rancang perangkat asesmen berbasis kelas untuk pembelajaran SPT di jurusan Teknik Otomotif memenuhi kriteria valid dan praktikal. Perangkat ini telah diimplementasikan di Jurusan teknik otomotif UNP Padang, pada semester Juli - Desember 2010.

\section{Deskripsi Data}

Setelah diberikan tes kepada mahasiswa diperoleh data tentang pemahaman konsep, kemampuan komunikasi, penalaran, koneksi, dan pemecahan masalah. Tabel 4 mendeskripsikan hasil belajar SPT mahasiswa.

Pada Tabel 4 terlihat bahwa rata-rata hasil belajar mahasiswa pada kelas eksperimen lebih tinggi dari rata-rata hasil belajar mahasiswa pada kelas kontrol, kecuali aspek kemampun penalaran dan pemecahan masalah. Rata-rata hasil belajar mahasiswa untuk aspek penalaran pada kelas eksperimen sama dengan rata-rata hasil yang dicapai mahasiswa pada kelas kontrol. Akan tetapi, untuk aspek kemampuan pemecahan masalah rata-rata hasil belajar mahasiswa di kelas eksperimen lebih rendah dari hasil rata-rata hasil yang dicapai oleh mahasiswa pada kelas kontrol.

Secara umum pada Tabel 4 juga dapat dilihat bahwa simpangan baku hasil belajar mahasiswa baik pada kelas kontrol maupun kelas eksperimen cenderung besar. Hasil belajar SPT mahasiswa dideskripsikan pada Tabel 5.

\section{Analisis Data}

Pada bagian ini dilakukan analisis data untuk menguji hipotesis penelitian. Uji yang digunakan adalah uji kesamaaan dua rata-rata. Sebelum melakukan uji kesamaan dua rata-rata, dilakukan uji normalitas

Tabel 4. Hasil belajar SPT Mahasiswa Jurusan teknik otomotif Padang

\begin{tabular}{|l|l|l|l|l|l|l|l|l|l|l|}
\hline \multirow{2}{*}{$\begin{array}{c}\text { Statistik } \\
\text { Sampel }\end{array}$} & \multicolumn{5}{|c|}{ Kelompok Eksperimen } & \multicolumn{5}{c|}{ Kelompok Kontrol } \\
\cline { 2 - 11 } & 1 & 2 & 3 & 4 & 5 & 1 & 2 & 3 & 4 & 5 \\
\hline Rata-rata X & 74,2 & 83,7 & 82,7 & 75,7 & 70,4 & 72,4 & 79,2 & 82,7 & 58,1 & 76,1 \\
\hline S & 9,4 & 12,4 & 14,8 & 15,6 & 9,0 & 22,7 & 5,5 & 11,1 & 21,3 & 26,1 \\
\hline N & 23 & 23 & 23 & 23 & 23 & 24 & 24 & 24 & 24 & 24 \\
\hline
\end{tabular}

Keterangan 1 = Pemahaman Konsep, $2=$ Komunikasi, $3=$ Penalaran, $4=$ Koneksi, $5=$ Pemecahan Masalah 
distribusi data menggunakan uji Lilliefors dan uji homogenitas variansi dua populasi menggunakan uji F.

Hipotesis penelitian yang diuji:

$$
\begin{aligned}
& H_{0}: \mu_{E}=\mu_{K} \\
& H_{1}: \mu_{E}>\mu_{K}
\end{aligned}
$$

yang mana $\mu_{E}=$ rata-rata hasil belajar mahasiswa di kelas eksperimen, dan $\mu_{\mathrm{K}}=$ rata-rata hasil belajar mahasiswa di kelas kontrol.

Setelah dilakukan uji normalitas menggunakan uji Lilliefors untuk $\alpha=0,01$ diperoleh data seperti terlihat pada Tabel 6.

Hasil pada Tabel 6 menunjukkan bahwa data hasil penelitian berdistribusi normal untuk tiap aspek yang diteliti. Uji selanjutnya yang dilakukan adalah uji homogenitas variansi dua populasi menggunakan uji F. Hasil uji homogenitas variansi untuk $\alpha=0,05$ dapat dilihat pada Tabel 7.

Mengacu pada hasil-hasil uji yang dicantumkan pada Tabel 7 dan Tabel 8, maka uji kesamaan dua rata-rata yang digunakan pada penelitian ini ada tiga jenis, yaitu: 1) Uji Wilcoxon, untuk kondisi salah satu kelompok data yang tidak berdistribusi normal; 1) Uji-t, untuk kondisi kedua kelompok data berdistribusi normal dan variansi data kedua kelompok homogen; 2) Uji-t, untuk kondisi kedua kelompok data berdistribusi normal dan varinsi data kedua kelompok tidak homogen. Jenis-jenis uji kesamaan dua ratarata yang dilakukan dalam penelitian ini secara rinci dapat dilihat pada Tabel 8.

Tabel 5. Hasil Belajar SPT Mahasiswa Jurusan Teknik Otomotif FT UNP

\begin{tabular}{|l|l|l|l|l|l|l|l|l|l|l|}
\hline \multirow{2}{*}{\begin{tabular}{c} 
Statistik \\
\multirow{2}{*}{}
\end{tabular}} & \multicolumn{5}{|c|}{ Kelompok Eksperimen } & \multicolumn{5}{c|}{ Kelompok Kontrol } \\
\cline { 2 - 11 } & 1 & 2 & 3 & 4 & 5 & 1 & 2 & 3 & 4 & 5 \\
\hline X & 55,9 & 65,5 & 76,7 & 72,1 & 48,7 & 53,1 & 48,2 & 44,9 & 60,3 & 40,8 \\
\hline S & 15,2 & 22,0 & 16,6 & 19,4 & 11,6 & 15,7 & 18,7 & 28,1 & 10,7 & 1,3 \\
\hline N & 42 & 42 & 42 & 42 & 42 & 35 & 35 & 35 & 35 & 35 \\
\hline
\end{tabular}

Keterangan: 1 = Pemahaman Konsep, 2 = Komunikasi, $3=$ Penalaran, $4=$ Koneksi, 5 = Pemecahan Masalah

Tabel 6. Hasil Uji Normalitas Data Penelitian

\begin{tabular}{|l|l|l|l|l|l|l|l|l|l|l|}
\hline \multirow{2}{*}{$\begin{array}{c}\text { Statistik } \\
\text { Sampel }\end{array}$} & \multicolumn{5}{|c|}{ Kelompok Eksperimen } & \multicolumn{5}{c|}{ Kelompok Kontrol } \\
\cline { 2 - 10 } & 1 & 2 & 3 & 4 & 5 & 1 & 2 & 3 & 4 & 5 \\
\hline $\begin{array}{l}\text { Jurusan } \\
\text { Teknik } \\
\text { Otomotif }\end{array}$ & $\sqrt{ }$ & $\sqrt{ }$ & $\sqrt{ }$ & $\sqrt{ }$ & $\sqrt{ }$ & $\sqrt{ }$ & $\sqrt{ }$ & $\sqrt{ }$ & $\sqrt{ }$ & $\sqrt{ }$ \\
\end{tabular}

Keterangan 1 = Pemahaman Konsep, 2 = Komunikasi, 3 = Penalaran, 4 = Koneksi, 5 = Pemecahan Masalah, $\sqrt{=}$ berdistribusi normal

Tabel 7. Hasil Uji Homogenitas Hasil Penelitian

\begin{tabular}{|l|l|l|l|l|l|}
\hline Aspek & $\begin{array}{l}\text { Pemahaman } \\
\text { Konsep }\end{array}$ & Komunikasi & Penalaran & Koneksi & $\begin{array}{l}\text { Pemecahan } \\
\text { Masalah }\end{array}$ \\
\hline $\begin{array}{l}\text { Jurusan } \\
\begin{array}{l}\text { Teknik } \\
\text { Otomotif }\end{array}\end{array}$ & Homogen & Homogen & $\begin{array}{c}\text { Tidak } \\
\text { Homogen }\end{array}$ & Homogen & $\begin{array}{c}\text { Tidak } \\
\text { Homogen }\end{array}$ \\
\hline
\end{tabular}


Setelah dilakukan uji hipotesis (uji kesamaan dua rata-rata) menggunkan uji-uji yang disebutkan pada Tabel 9 untuk $\alpha=0,05$, diperoleh kesimpulan seperti tersaji pada Tabel 9.

Dalam hal ini ditemukan bahwa pemahaman konsep, kemampuan komunikasi, penalaran, koneksi, dan pemecahan masalah kelompok mahasiswa yang diinilai dengan perangkat asesmen berbasis kelas lebih tinggi daripada kelompok mahasiswa yang diinilai dengan paper and pencil test. Dengan demikian, secara umum dapat dikatakan: pemahaman konsep, kemampuan komunikasi, penalaran, koneksi, dan pemecahan masalah kelompok mahasiswa Jurusan Teknik Otomotif yang dinilai dengan perangkat asesmen berbasis kelas lebih tinggi daripada kelompok mahasiswa yang dinilai dengan paper and pencil test.

\section{Bahasan}

Berdasarkan hasil penelitian bahwa prototype perangkat asesmen berbasis kelas yang telah dikembangkan untuk pembelajaran SPT di Jurusan Teknik Otomotif memenuhi kriteria valid dan praktis, secara khusus, perangkat asesmen yang dikembangkan valid dan praktis untuk menilai penelitian menunjukkan bahwa perangkat asesmen berbasis kelas yang dikembangkan untuk pembelajaran SPT di Jurusan Teknik Otomotif efektif dalam mengembangkan pemahaman konsep, kemampuan komunikasi, penalaran, dan pemecahan masalah mahasiswa.

Hasil belajar kelompok mahasiswa yang dinilai dengan perangkat asesmen berbasis kelas lebih baik dari hasil belajar kelompok mahasiswa yang diinilai dengan paper and pencil test. Hal ini disebabkan karena potensi yang memiliki mahasiswa dapat berkembang selama pelaksanaan asesmen berbasis kelas.

Seperti diuraikan terdahulu, asesmen berbasis kelas bertujuan untuk mengungkapkan apa yang diketahui dan apa yang dilakukan oleh mahasiswa. Melalui asesmen berbasis kelas, mahasiswa Jurusan Teknik Otomotif telah mendapat kesempatan untuk menunjukan potensi mereka dalam berkomunikasi tentang SPT, bernalar, dan melihat koneksi antara materi ajar dengan materi-materi lain yang terkait, seperti mata kuliah Elemen Mesin dan Permesinan. Hal seperti ini tidak mereka temui dalam paper and pencil test yang cenderung hanya mengukur aspek kognitif yang dangkal. Dalam asesmen berbasis kelas

Tabel 8. Uji Kesaman Dua Rata-rata yang Digunakan dalam Penelitian

\begin{tabular}{|l|c|c|c|c|c|}
\hline Aspek & $\begin{array}{l}\text { Pemahaman } \\
\text { Konsep }\end{array}$ & Komunikasi & Penalaran & Koneksi & $\begin{array}{l}\text { Pemecahan } \\
\text { Masalah }\end{array}$ \\
\hline $\begin{array}{l}\text { Jurusan } \\
\text { Teknik } \\
\text { Otomotif }\end{array}$ & Uji-t & Uji-t & Uji-t & Uji-t & Uji-t \\
\hline
\end{tabular}

Tabel 9. Hasil Uji Hipotesis Penelitian

\begin{tabular}{|l|l|l|l|l|l|}
\hline \multicolumn{1}{|c|}{ Aspek } & $\begin{array}{l}\text { Pemahaman } \\
\text { Konsep }\end{array}$ & Komunikasi & Penalaran & Koneksi & $\begin{array}{l}\text { Pemecahan } \\
\text { Masalah }\end{array}$ \\
\hline $\begin{array}{l}\text { Jurusan } \\
\text { Teknik } \\
\text { Otomotif }\end{array}$ & $\mathrm{H}_{0}$ ditolak & $\mathrm{H}_{0}$ ditolak & $\mathrm{H}_{0}$ ditolak & $\mathrm{H}_{0}$ ditolak & $\mathrm{H}_{0}$ ditolak \\
\hline
\end{tabular}

pemahaman konsep, kemampuan pemecahan masalah, penalaran kumunikasi, dan koneksi mahasiswa.

Perangkat asesmen berbasis kelas telah diimplementasikan di Jurusan Teknik Otomotif, untuk menyelidiki efektivitasnya. Secara umum hasil mahasiswa berkompetisi dengan diri mereka sendiri sehingga mengurangi rasa takut dalam menghadapi test.

Perangkat asesmen berbasis kelas pembelajaran SPT efektif dalam mengembangkan pemahaman konsep, kemampuan komunikasi, 
penalaran, dan pemecahan masalah mahasiswa. Pengembangan pemahaman konsep, kemampuan komunikasi, dan pemecahan kemampuan penalaran diperlukan pembiasaan. Dengan sering menggunakan perangkat asesmen berbasis kelas mahasiswa akan semakin mampu melakukan pemahaman konsep, kemampuan komunikasi, penalaran, dan pemecahan masalah yang ada dalam mata kuliah SPT.

Konsep merupakan generalisasi dari sekelompok gejala tertentu, dan dapat dipakai untuk menggambarkan berbagai fenomena yang sama. Belajar konsep artinya mahasiswa mampu memberi respon terhadap stimulus yang hadir melalui karakteristik abstraknya. Melalui pemahaman konsep mahasiswa mampu mengidentifikasikan hal lain yang berbeda atributnya; baik ukuran, warna, maupun materinya. Dalam kenyataan konsep dapat mempunyai tingkat generalisasi yang berbeda. Semakin dekat suatu konsep kepada realita semakin mudah konsep tersebut diukur dan dievaluasi. Konsep-konsep pada teknik otomotif menggambarkan gejala nyata yang konkrit (dapat diketahui panca indera). Dengan demikian konsep pada SPT dapat dinilai melalui pemahaman konsep tersebut, seperti konsep momen pada transmisi atau dfrensial.

Komunikasi dalam pendidikan otomotif dapat dikembangkan dengan cara memberi mahasiswa berbagai kesempatan untuk mendengarkan, berbicara, menulis, membaca, dan menyajikan ideide baik dalam bentuk pembelajaran, laporan atau portofolio. Kemampuan komunikasi mahasiswa dikembangkan melalui kerja kelompok, presentasi, dan membuat laporan praktek. Laporan praktek akan mendorong mahasiswa untuk menyampaikan kegiatan yang terjadi selama praktek, sedangkan presentasi memberi kesempatan kepada mahasiswa untuk menyimpulkan atau menjelaskan suatu topik atau kasus.

Kemampuan komunikasi asesmen berbasis kelas dinilai/diakses melalui pembuatan laporan, dan laporan ini didesain dalam bentuk portofolio, sehingga tampak perkembangan kemajuan mahasiswa dan setiap laporan dikoreksi dan dinilai secara bekelanjutan. Dosen umumnya membuat laporan praktek dan menjadi rutinitas dari proses pembelajaran terutama kelas praktek.

Penalaran adalah kemampuan utama lain yang ingin dikembangkan melalui pembelajaran otomotif. Struktur otomotif yang terdiri dari sistem, meka- nisme, serta sifat induktif dari otomotif, membutuhkan kemampuan penalaran empirik yang baik untuk memahaminya. Asesmen berbasis kelas dikembangkan melalui berpikir sistem yang ada pada mekanisme pemindah tenaga. Secara induktif, seperti pada mekanisme transmisi (versnelling), jika posisi gigi tiga sudah masuk (terkunci) maka posisi gigi lain bebas. Penalaran dapat dilakukan secara induktif (informal) maupun deduktif (formal), kedua hal ini ada pada matakuliah SPT.

Pelaksanaan asesmen melalui pencil and paper test dalam pembelajaran selama ini cenderung mengisolasi otomotif dari bidang ilmu lain, sehingga kemampuan koneksi mahasiswa tidak berkembang. Akibatnya mahasiswa sangat sulit mengaplikasikan dan menarik generalisasi serta mencari relasi dengan bidang ilmu lain. Melalui teknik asesmen berbasis kelas yang bervariasi, mahasiswa diarahkan untuk melihat koneksi antar konsep-konsep otomotif, maupun koneksi antara otomotif dengan bidangbidang lain, seperti relasi dengan bidang fisika, kimia, mekanika, permesinan atau bidang lainnya.

Pemecahan masalah pada matakuliah SPT adalah proses menemukan penyebab kerusakan dan mengatasi suatu kerusakan yang terjadi dalam SPT dan situasi dalam keadaan sehariannya. Kemampuan pemecahan masalah dapat ditingkatkan melalui memberi kesempatan kepada semua mahasiswa untuk belajar bahwa ada banyak cara untuk menyelesaikan suatu kerusakan (berpikir divergen) dan ada lebih dari satu solusi yang mungkin dari suatu kerusakan. Kemudian asesmen dikembangkan melalui indikator kegiatan eksplorasi, berpikir komprehensif, dan bernalar secara sistematis dan logis.

Asesmen yang memuat pemecahan masalah dapat memberi kesempatan sekaligus mengarahkan mahasiswa melakukan investigasi, mengekplorasi pola-pola dan berpikir secara kritis. Asesmen pemecahan masalah dikembangkan dari kasus-kasus kerusakan yang terjadi pada SPT. Dengan memahami penyebab dan akibat kerusakan yang terjadi pada SPT dapat meningkatkan kemampuan pemecahan masalah mahasiswa.

\section{Simpulan}

Berdasarkan hasil penelitian disimpulkan: Pemahaman konsep, kemampuan komunikasi, penalaran, kemampuan koneksi dan pemecahan 
masalah kelompok mahasiswa Jurusan Teknik Otomotif FT UNP Padang yang dinilai dengan perangkat asesmen berbasis kelas lebih tinggi daripada kemampuan kelompok mahasiswa yang dinilai dengan paper and pencil tes.

Berdasarkan uraian yang dikemukakan di atas dapat disimpulkan bahwa perangkat asesmen berbasis kelas yang telah dikembangkan untuk pembelajaran SPT lebih tinggi daripada kelompok mahasiswa yang dinilai dengan paper and pencil test. Selain itu, pembelajaran SPT efektif dalam meningkatkan pemahaman konsep, kemampuan komunikasi, penalaran, koneksi dan pemecahan masalah mahasiswa.

\section{Saran}

Perangkat asesmen berbasis kelas yang telah dirancang untuk pembelajaran SPT di Jurusan Teknik Otomotif efektif dapat meningkatkan pemahaman konsep, kemampuan komunikasi, penalaran, koneksi, dan pemecahan masalah dalam pembelajaran matakuliah SPT. Perangkat asesmen berbasis kelas potensial digunakan untuk menilai hasil belajar mahasiswa. Oleh sebab itu, kepada dosen mata kuliah SPT di jurusan Teknik Otomotif disarankan untuk mengembangkan dan menggunakannya. Selain itu, dapat untuk memberi variasi dalam pelaksanaan asesmen dan menarik minat mahasiswa dalam belajar Sistem Pemindah Tenaga.

\section{Pustaka Acuan}

Buku Pedoman Akademik UNP tahun 2007/2008.

Depdiknas. 2003. Pengembangan Sistem Penilaian. Jakarta: Depdiknas.

Guskey, T.R. 2000. Evaluating Professional Development. Thousand Oaks: SAGE.

Holmes, Emma E. 1995. New Directions in Elementary School Mathematics. New Jersey: Prenctice Hall, Inc.

McMillan, James H. 2001. Classroom Assessment: Principles and Practice for Elective

Instruction. Allyn and Bacon: Boston.

Ott, Jack. 1994. Alternative Assessment. New York: Glencoe McGraw Hill.

Plomp, Tjeerd. 2002. Some Reflections on 'Theory of Development' in development research. University of Twente, The Netherlands.

Van den Akker, J. 1999. Principle and methods of Development Research. Kluwer Academic Publisher : Nederland. 